\title{
STUDIES ON THE GROWTH INHIBITING AND NON-CYTOTOXIC EFFECTS OF TOCOTRIENOLS ON SELECTED CANCER CELL LINES
}

\author{
Aleksandra Szulczewska-Remi ${ }^{\boxplus}$, Małgorzata Nogala-Kalucka² \\ ${ }^{1}$ Department of Controlling, Financial Analysis and Valuation, Poznan University of Economics and Business \\ Powstanców Wlkp. 16, 61-895 Poznań, Poland \\ ${ }^{2}$ Department of Biochemistry and Food Analysis, Poznań University of Life Sciences \\ Mazowiecka 48, 61-623 Poznań, Poland
}

\begin{abstract}
Background. Tocotrienols found in certain plant oils, like palm, rice bran, grapeseed and annatto seeds, have been reported to possess beneficial properties for humans, including cancer prevention. Since studies on their beneficial effects on human breast cancer cells have been extensively reviewed, the current understanding of how tocotrienols affect other cancer cells deserves further research. Therefore, the aim of this study was to investigate the antiproliferative and non-cytotoxic effects of tocotrienols on human hepatoma $\mathrm{HepG}_{2}$ and colon colorectal Caco-2 cell cultures.

Materials and methods. The cells were exposed to alpha-, beta-, gamma- or delta-tocotrienols at various concentrations and the antiproliferative activities were measured using MTS-based CellTiter 96 followed by a methylene blue assay for counting cells to evaluate the potential toxicity.

Results. The research on $\mathrm{HepG}_{2}$ showed statistically similar cytotoxic effects for both beta- and delta-T3 with no effects for alpha- and gamma-T3. Promising results were found for alpha-, beta- and gamma-T3 against CaCo-2.

Conclusion. The exact reasons for the sensitivity of liver cancer cells to tocotrienols are unknown. Inhibition is time and dose-dependent, therefore tocotrienols' homologs show very high toxic or no effects. Tocotrienols appeared to be effective against colon cancer cells. Still, future investigation is necessary to explain the different mechanism of actions to support the antiproliferative effects of these homologs against colon cancer cells.
\end{abstract}

Keywords: tocotrienols (-T3), cell proliferation, cytotoxicity, liver cancer cell lines $\mathrm{HepG}_{2}$, colon cancer cell lines Caco-2

\section{INTRODUCTION}

Plant oils are common sources of tocochromanols (tocopherols and tocotrienols) that play an important role in human nutrition and health. While tocopherols (-T) are commonly found in popular oils (i.e., soya, sunflower and wheat germ), tocotrienols (-T3) have also been reported in certain plant oils like palm, rice bran, grapeseed and annatto seeds (Szulczewska-Remi et al., 2019). The fact that tocotrienols exhibit antioxidant properties has persuaded many authors to study their ability to prevent chronic diseases, especially cancer, one of the most fatal diseases of today. Evidence suggests that tocotrienols have an anti-cancer

Authors would like to thank the Kosciuszko Foundation for its substantial contribution to the study.

${ }^{\circledR}$ Aleksandra.Szulczewska-Remi@ue.poznan.pl, https://orcid.org/0000-0001-9043-8855 
effect when using doses that do not affect normal cell growth and function (Sylvester and Shah, 2005), and they are also involved in immunoregulatory and antibody production processes and tumor resistance. It has been shown that the anticancer properties of tocotrienols are mediated via the inhibition of tumor metastasis (De Silva et al., 2016), apoptosis induction, cell cycle modulation, antioxidant activity and angiogenesis inhibition. Tocotrienols uniquely impair the nuclear factor-B signaling pathway, suppress 3-hydroxy-3-methylglutaryl-coenzyme A (HMG-CoA) reductase activity, mammalian DNA polymerases, and some protein tyrosine kinases, therefore potentially preventing cancer (Kannappan et al., 2012).

Absorption of tocotrienols through the skin combats oxidative stress induced by UV rays or ozone. Some breast cancer cells preferentially accumulate tocotrienols rather than tocopherols, which partially explains the greater biopotency of tocotrienols as compared to tocopherols (McIntyre at al., 2000). Besides, the biological activities of tocopherols and tocotrienols are distinguished by the number and location of methyl groups on their chroman rings. It was reported by Abu-Fayyad and Nazzal (2017) that tocotrienols' antitumor properties result from their chemical structure, specifically their methyl substituents' number and position, hence gamma- and delta-T3 which lack the 5-methyl substituents are more potent cancer chemopreventive agents than alpha-T and alpha-T3. According to Kline and coworkers (2003), alpha-T is ineffective as an antiproliferative agent, while gamma- and delta- $\mathrm{T}$ show promise. Epidemiological and experimental studies suggest that gamma-T shows significantly greater inhibitory effects on cell growth than alpha-T (Campbell at al., 2003).

However, Schwenke (2002) observed only alpha-, beta-, gamma- and delta-T3 potent antiproliferative and proapoptotic effects against breast cancer with no effect for tocopherols. Also, the tocotrienol rich fraction (TRF) and each individual tocotrienol of tocotrienols both prevent the growth of human breast cancer cells irrespective of estrogen receptor (ER), whereas alpha-T do not cause such effects (Guthrie at al., 1997). These beneficial properties of tocotrienols have also been reported as suppressing the growth of hormone-responsive (MCF7) and unresponsive (MDA-MB-231) human breast cancer cells that have become resistant to growth inhibition by some antiestrogens like tamoxifen (Theriault at al., 1999). In 2010, Samant et al. (2010) suggested the antiproliferative effects of gamma-T3 accompanyed by a reduction in cell cycle progression from $G(1)$ to $S$ on the same cell line. There is evidence to show that gamma-T3 impairs breast cancer cell proliferation by suppressing HMG-CoA (Wali et al., 2009) and induces apoptosis through DR-5, death receptor 5 and CHOP, epidoplasmic reticulum stress marker (Park et al., 2010). Pierpaoli and others (2010) also suggested that gamma-T3 and delta-T3 reduce cell viability based on half maximal inhibitory concentration, and induces apoptosis through mitochondrial pathway and the expression of some senescent-like growth arrest markers. It was also recently demonstrated that gamma- and delta-T3 induce MDA-MB-231 and MCF-7 cell apoptosis by the binding and the activation of the estrogen receptor-b (Comitato et al., 2017). The TRF of palm oil and individual forms of tocotrienols could also constrain the growth of some other human breast cancer cell lines, like ZR-75-1 (Nesaretnam at al., 2000). Moreover, T3 in combination with chemotherapeutic drugs or other dietary components like tamoxifen or citrus flavonoids act synergistically in inhibiting the growth of ductal carcinoma of the breast (Guthrie at al., 1997). Bachawal and colleagues (2010) confirmed combined gamma-T3 and erlotinib or gefitinib while Hsieh and $\mathrm{Wu}(2008)$ studied the combinatorial synergy of gamma-T3, EGCG and resveratrol in suppressing mammary tumor cell proliferation.

Since studies on the beneficial effects of tocotrienols on human breast cancer cells have been reviewed recently. The current understanding of the function of tocotrienols in other cancer cell lines deserves further research. It was found that gamma-T3 constrains the growth of murine B16 (F10) melanoma cells, especially the growth of human breast adenocarcinoma (MCF-7) and human leukemic (HL-60) cells (Chang et al., 2009). Tocotrienols also exert their antiproliferative effects on H69 lung carcinoma, HeLa cervical epitheloid carcinoma, and P388 leukemia cells (Komiyama at al., 1989). There is evidence confirming that redox-silent analogue of alpha-tocotrienol (T3) shows potential anticarcinogenic properties in a lung cancer cell (A549 cell) (Kashiwagi et al., 2008). Other findings indicate that gamma-T3 constrains the growth 
of human pancreatic tumors (Kunnumakkara et al., 2010) while $d$-delta-tocotrienol induces the suppression of human pancreatic cancer cell lines (Hussein and Mo, 2009). Also, in another study, gamma-T3 selectively killed prostate cancer cells and sensitized the cells to docetaxel-induce apoptosis (Yap et al., 2010). Recently, tocotrienols have also been proven effective against blood, brain, cervical and stomach cancers (Sailo et al., 2018).

Still, our understanding of the role of tocotrienols in cancer prevention, especially for less extensive explored cancer cell lines, is a source of enquiries. One such example is hepatic cancer, the seventh most invasive cancer in the world, with an estimated eight hundred forty one thousand new cases every year, and colorectal cancer, the fourth most common cancer with almost one million one hundred thousand new cases annually (Bray et al., 2018). Therefore, the aim of this study was to examine the antiproliferative effects of each individual tocotrienol homolog on human hepatoma $\left(\mathrm{HepG}_{2}\right.$ ) and colon colorectal (Caco-2) cancer cells, together with their cytotoxicity.

\section{MATERIALS AND METHODS}

\section{Chemicals}

Standards of beta-, gamma- and delta-tocotrienols were purchased from Calbiochem (EMD Biosciences, Inc., La Jolla, CA). Alpha-T3 standard came from ICN Biomedicals Inc (Aurora, OH). The $\mathrm{HepG}_{2}$ and Caco-2 cells were delivered from American Type Culture Collection (ATCC) (Rockville, MD), and the MTS-based Cell Trier 96 nonradioactive cell proliferation assay was from Promega (Madison, WI). Cells were maintained in WME supplemented with $5 \% \mathrm{FBS}, 5 \mathrm{mg} / \mathrm{ml}$ insulin, $0.5 \mathrm{mg} / \mathrm{ml}$ hydrccortisone, $2 \mathrm{mg} / \mathrm{ml}$ glucagon, $100 \mathrm{mg} / \mathrm{ml}$ Gentamicin and $10 \mathrm{mM}$ HEPES (CM) according to Liu at al. (1997) and were incubated in 5\% $\mathrm{CO}_{2}$ at $37 \pm 1^{\circ} \mathrm{C}$.

\section{Determination of inhibition activity on cancer cell proliferation}

The cell cultures were exposed to various concentrations of tocotrienols for a 96-hour growth period. Antiproliferative activities were measured using an MTS-based cell titer 96 nonradioactive assay. Cell proliferation was established by the ability of viable cells to reduce 3-(4,5-dimethylthiazol-2-yl)-5-(3-carboxymethoxyphenyl)-2-(4-sulfenyl)-2H-tertrazolium (MTS) to formazan. Cells were seeded at a density of $2.5 \times 10^{4} / \mathrm{mL}$ in the growth media and were placed in each well of a 96-well flat-bottom plate ( 2500 cells in $100 \mathrm{~mL}$ into each 96-plate well). MTS absorbance was measured using a MRX II DYNEX spectrophotometer (Dynex Technologies, Inc., Chantilly, VA) at $490 \mathrm{~nm}$ wavelength for each tocotrienol homolog in a range from 0 to $50 \mathrm{mM}$ concentration in a mixture of a culture medium and $100 \%$ ethanol, compared to the control, where the final ethanol concentration was less than $0.05 \%$. Results from three replications for each concentration were used to determine the mean of half the effective median concentration $\left(\mathrm{EC}_{50}\right)$ expressed in $\mathrm{mM} \pm \mathrm{SD}$.

\section{Measurement of cytotoxicity}

The methylene blue assay for counting cells was applied to assess the potential toxicity of tocotrienols toward $\mathrm{HepG}_{2}$ and Caco-2 cancer cells, following the procedure described by Oliver and others (1989). The cell cultures were incubated to various concentrations of tocotrienols for a 96hour growth period. Monolayer-forming cells at $\mathrm{pH} 8.5$ were placed in each of the 96-well plate $(2500$ cells were seeded in $100 \mathrm{~mL}$ into each 96-plate well). The cytotoxicity of the tumor cells was determined by measuring the absorbance of the dye released from the cell monolayer after lowering the $\mathrm{pH}$ using a MRX II Speaker Spectrophotometer MRX II (Dynex Technologies, Inc., Chantilly, VA, USA) at a wavelength of $490 \mathrm{~nm}$ for each tocotrienol homolog in a concentration range between 0-50 mM, which was compared to the control sample. The solvent eluting the monolayer of cells contained acidified ethanol whose presence guaranteed a linear correlation between the absorbance of the dye and the number of cells. All analyses were performed at least 3 times.

\section{Western Blot analysis of proliferating cell nuclear antigen (PCNA) protein expression}

Proliferating cell nuclear antigen (PCNA) is involved in a wide range of cellular functions including DNA replication and repairing of proliferating cells. The detection of proliferating cell nuclear antigen in each Caco-2 treated with tocotrienols at different concentrations $(5-45 \mathrm{mM})$ of cell extract fraction was studied 
by Western blot analysis, a commonly used technique to study gene expression and protein synthesis.

The Caco- 2 cancer cell lines were plated at a density of $1.5 \times 10^{6}$ cells/well on 6 -well plates and after 24 hours were treated with homolog tocotrienols of various concentrations. In addition, two controls were maintained in a medium (control 1) and in a medium with $0.1 \%$ Fetal Bovine Serum (FBS; control 2). The extraction was carried out according to Liu et al. (1997) to release the cytosolic cell fraction using a Radioimmunoprecipitation assay buffer (RIPA buffer; 50 $\mathrm{mM}$ Tris $\mathrm{pH} 7.4,1 \%$ Igepal, $150 \mathrm{mM} \mathrm{NaCl}, 1 \mathrm{mM}$ EDTA into $100 \mathrm{ml}$ water) with protease inhibitors (apoprotein, leupeptin, pepstatin, PMSF - phenyl methyl sulfonyl fluoride, sodium fluoride, sodium orthovanadate). Cell lysates were prepared using a Sigma Diagnostics Micro Protein Determination Kit (Sigma Diagnostics, St. Louis, MO, USA). Samples and a marker (biotinylated marker, New England Biolabs Kit, New England Biolabs, UK) were subjected to electrophoresis through SDS-PAGE polyacrylamide gel and a running buffer at $\mathrm{pH} 8.3$ (Tris Base, glycine, SDS). The analysis was performed at constant current (40 mA) and voltage (150V) for about 3 hours. Proteins from the gels were transferred onto membranes at $100 \mathrm{~mA}$ and $30 \mathrm{~V}$ overnight using a transfer buffer at pH 8.3 (Tris, glycine, methanol) in a transfer apparatus. The membranes were then blocked with a blocking buffer (PBS, pH 7.18, skimmed milk powder) and washed with water. The blocked membranes were then immersed with specific primary PCNA antibodies (New England Biolabs, UK) for 24 hours at $4^{\circ} \mathrm{C}$. The next day, the membranes were washed in water and PBS was added to a mixture of PBS-Tween, skimmed milk powder, anti-Mouse $\operatorname{IgG}$ and antibiotin antibody (New England Biolabs, UK). After two hours, the membranes were washed with water and PBS-Tween and soaked in an activation buffer (water buffer with Luminol and peroxide (New England Biolabs, UK)). Images from the membranes were induced onto a film (Eastman Kodak Company, Rochester, NY, USA) in a darkroom. All experiments were repeated two times.

\section{Statistical analysis}

Statistical analyses were performed applying a oneway analysis of ANOVA variance in Statistica 12 (StatSoft Inc., Tulsa, OK., USA) and Minitab Softwares
(Minitab Inc., State College, PA, USA). If significant differences were found, post-hoc analysis was performed adapting the Tukey test to find homogeneous groups. Also, correlation was used to determine the relationship between larger number of variables.

\section{RESULTS AND DISCUSSION}

In this study, we examined the effects of tocotrienol homologs on liver (Hep- $\mathrm{G}_{2}$ ) and colon (Caco-2) cancer cell lines. Cancer cells were treated with tocotrienols at a range of concentrations varying from $0-50$ $\mathrm{mM}$ for 96 hours of cell proliferation. The $\mathrm{HepG}_{2}$ results are summarized in Figure 1 showing that proliferation was impaired in a dose-dependent manner after subjection to tocotrienols. However, alpha- and gamma-T3 did not constrain liver cancer cells; betaT3 had clear antiprolifarative effects, while delta-T3 was unusually inhibitory.

In the previous study, Wada et al. (2005) treated $\mathrm{HepG}_{2}$ cells with $40 \mathrm{mM}$ of all tocotrienol homologs for 1,3 and 5 days and noticed suppressed cell proliferation for all forms of tocotrienols. However, the authors observed delta-T3 to have more significant antiproliferative effects and beta-T3 had the next highest

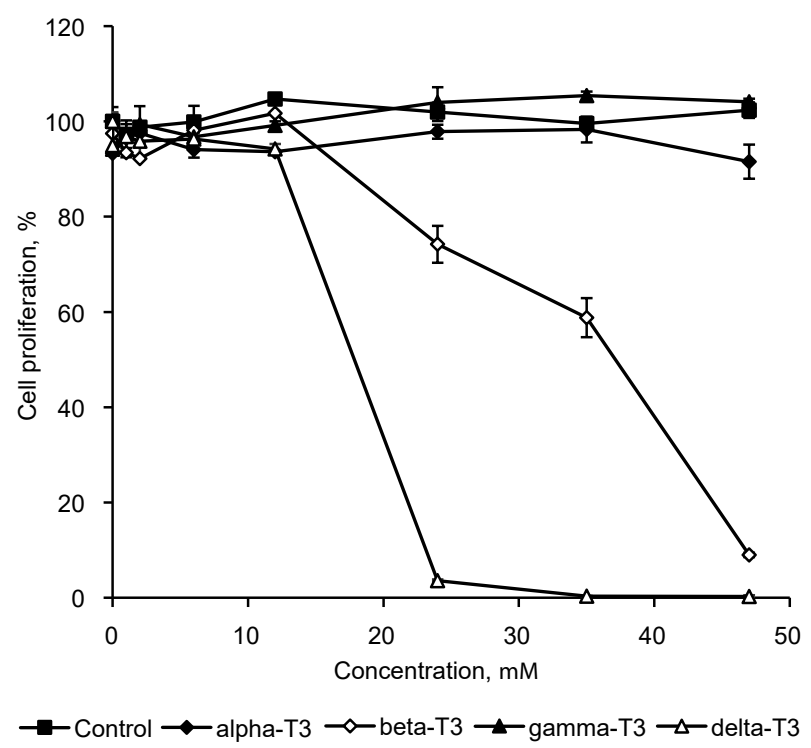

Fig. 1. Inhibition of $\mathrm{HepG}_{2}$ human liver cancer cell proliferation by tocotrienols. Data are presented as means \pm SEM, $n=3$ 
Szulczewska-Remi, A., Nogala-Kalucka, M. (2020). Studies on the growth inhibiting and non-cytotoxic effects of tocotrienols on selected cancer cell lines. Acta Sci. Pol. Technol. Aliment., 19(2), 139-147. http://dx.doi.org/10.17306/J.AFS.2020.0787

Table 1. Inhibitory concentrations $50 \%\left(\mathrm{IC}_{50}\right)$ and cytotoxic concentrations $\left(\mathrm{CC}_{50}\right)$ on $\mathrm{HepG}_{2}$ human liver cancer cell proliferation by tocotrienols

\begin{tabular}{lrl}
\hline Tocotrienols (T3) & $\mathrm{IC}_{50}, \mathrm{mM}$ & $\mathrm{CC}_{50}, \mathrm{mM}$ \\
\hline beta- & $33 \pm 0.4^{\mathrm{b}}$ & $32.4 \pm 1.9^{\mathrm{b}}$ \\
delta- & $21.5 \pm 0.2^{\mathrm{a}}$ & $21.2 \pm 0.5^{\mathrm{a}}$ \\
\hline
\end{tabular}

Data are presented as means $\pm \mathrm{SEM}, n=3$. Letters at $\mathrm{IC}_{50}$ and $\mathrm{CC}_{50}$ values indicate statistically different observations at $p<$ 0.05 . The $\mathrm{IC}_{50}$ value for alpha- and gamma-T3 could not be calculated from the dose-response curve.

potency, while alpha- and gamma-T3 were somewhat weaker. Moreover, all homologs were associated with proliferative inhibition on days 3 and 5 , which clearly confirms the results collected in Figure 1 after 96 hours of treatment. The order of the inhibitory effects was delta-T3 $>$ beta-T3 $>$ alpha-T3 = gamma-T3

Based on a dose-response curve, the $\mathrm{IC}_{50}$ value indicating the half maximal inhibitory concentration of the tocotrienol homolog was calculated using regression analysis. Table 1 shows the $\mathrm{IC}_{50}$ values of betaand delta-T3. There was no significant effect on the cell proliferation of alpha- and gamma-T3 on $\mathrm{HepG}_{2}$ cells, however, delta-T3 had a lower $\mathrm{IC}_{50}(21.5 \mathrm{mM})$ which was significantly different to beta-T3 $(33 \mathrm{mM})$.

Cytotoxicity is one of the parameters which determines the effectiveness of the compound against cancer. The methylene blue assay is applied to estimate in vitro such an effect, which depends on the chemical structure. The cytotoxicity curves and $\mathrm{CC}_{50}$ values are presented in Figure 2 and Table $1 . \mathrm{CC}_{50}$ was at concentrations of $32.4 \mathrm{mM}$ for beta-T3 and $21.2 \mathrm{mM}$ for delta-T3. The difference in the cytotoxic effects of betaand delta-T3 was also significant. Yano et al. (2005) also noticed the cytotoxicity of the synthetic alpha-T3 analogue (6-o-carboxypropyl-alpha-tocotrienol-T3E) relative to A549 cells (human lung adenocarcinoma cells) and explained the fact by cell accumulation in the G1 cell cycle phase and consequent apoptosis.

The exact reasons for the sensitivity of liver cancer cells to tocotrienols are unknown. It is time and dosedependent inhibition, therefore tocotrienol homologs show very high toxic or no effects. Previous studies by Aida et al. (2007) and Sazli et al. (2015) investigated the antiproliferative effects of gamma-T3 in $\mathrm{HepG}_{2}$,

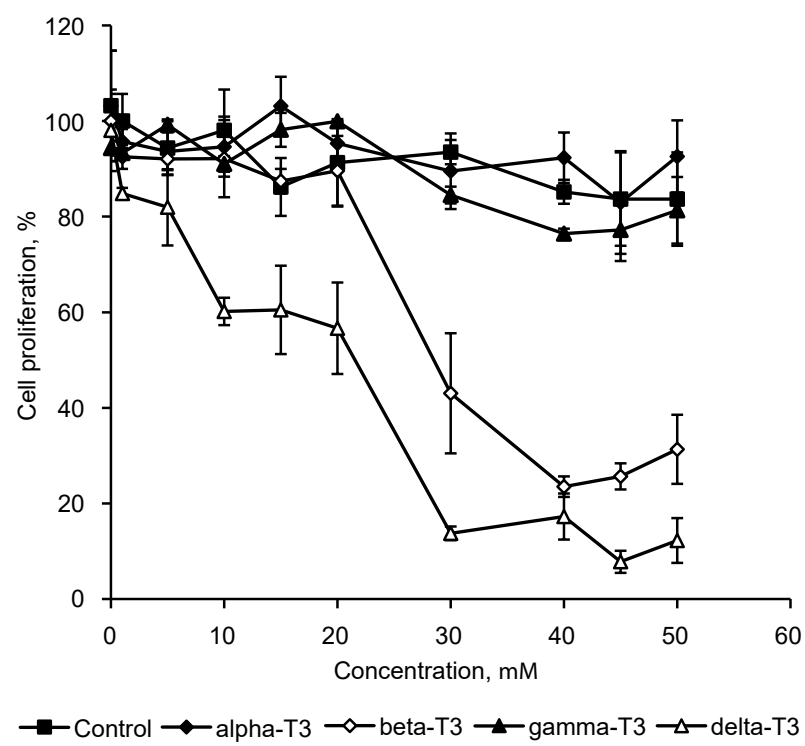

Fig. 2. The cytotoxicity of tocotrienols in the $\mathrm{HepG}_{2}$ human liver cancer cells. Data are presented as means $\pm \mathrm{SEM}, n=3$

however, the authors used different treatment conditions (48-hour gamma-T3 treatment) and a higher gamma-T3 dose (170 $\mathrm{mM}$ and $70 \mathrm{mM}$ respectively). Zaiden et. al. (2010) showed that beta-, gamma- and delta-T3 significantly suppressed the proliferation of human hepatoma cells at concentrations higher than $20 \mathrm{mM}$ for a 24-hour treatment. However, Rajendran et al. (2011) treated $\mathrm{HepG}_{2}$ with the $50 \mathrm{mM}$ gammaT3 for 4 hours, which was sufficient to suppress interleukin-6-induced STAT3 and JAK2 phosphorylation. It was also found that gamma-T3 influenced the expression of STAT3-regulated gene products causing the inhibition of proliferation, and induced apoptosis and enhanced the cell death effects caused by paclitaxel and doxorubicin, chemotherapeutic drugs used for hepatocellular carcinoma.

Previous research by Shibata et al. (2015) demonstrated that delta-T3 could be used as a novel anticancer agent against human colorectal adenocarcinoma. Similarly, Yang et al. (2010) suggested the synergistic actions of atorvastatin with gamma-T3 and celecoxib against human colon cancer cells. Figure 3 illustrates the effects of tocotrienols on colon cancer Caco-2 cell proliferation. For all four homologs, a positive effect on cell growth inhibition was observed as compared to the control i.e. without an antioxidant. 


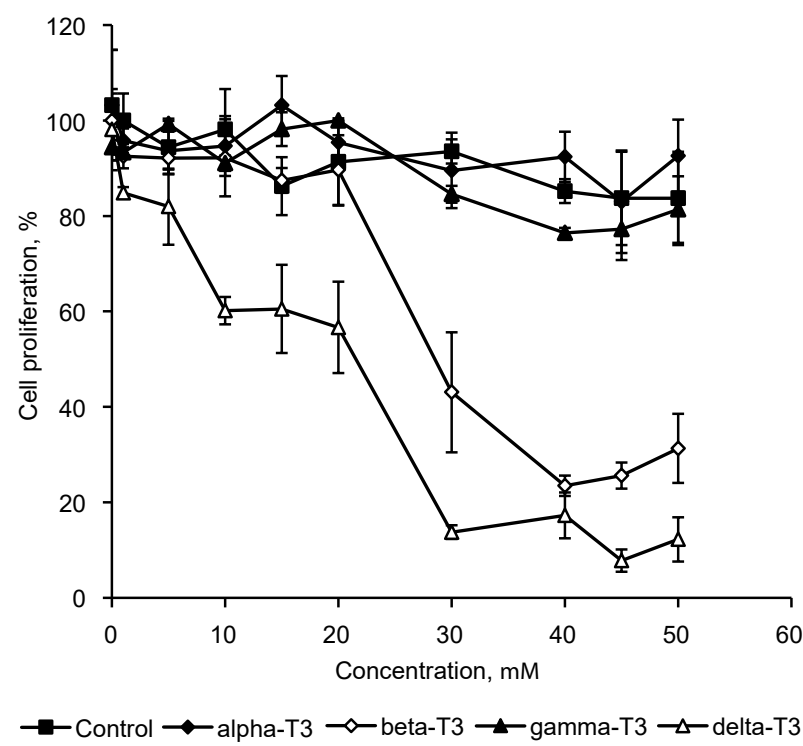

Fig. 3. Inhibition of Caco-2 human colon cancer cell proliferation by tocotrienols. Data are presented as means \pm SEM, $n=3$

Additionally, the half maximal inhibition concentration $\mathrm{IC}_{50}$ was calculated for all tocotrienols (Table 2) with the highest being alpha-T3 concentration $\left(\mathrm{IC}_{50}=56 \mathrm{mM}\right)$, followed by gamma-T3 $\left(\mathrm{IC}_{50}=\right.$ $41.4 \mathrm{mM})$, beta-T3 $\left(\mathrm{IC}_{50}=22.1 \mathrm{mM}\right)$ and delta-T3 $\left(\mathrm{IC}_{50}=16.8 \mathrm{mMl}\right)$. There were statistically significant differences between all homologs, therefore they were ranked in the following order: delta-T3 $>$ beta-T3 $>$ gamma-T3 > alpha-T3.

When analyzing the cytotoxicity of tocotrienols to Caco-2 cells, statistically different cytotoxic concentra-

Table 2. Inhibitory concentrations $50 \%\left(\mathrm{IC}_{50}\right)$ and cytotoxic concentrations $\left(\mathrm{CC}_{50}\right)$ on Caco-2 human colon cancer cell proliferation by tocotrienols

\begin{tabular}{lrr}
\hline Tocotrienols (-T3) & $\mathrm{IC}_{50}, \mathrm{mM}$ & $\mathrm{CC}_{50}, \mathrm{mM}$ \\
\hline alpha- & $56 \pm 2.5^{\mathrm{d}}$ & $72.7 \pm 8.4^{\mathrm{c}}$ \\
beta- & $22.1 \pm 0.1^{\mathrm{b}}$ & $49 \pm 0.7^{\mathrm{b}}$ \\
gamma- & $41.4 \pm 0.7^{\mathrm{c}}$ & $152.4 \pm 5.1^{\mathrm{d}}$ \\
delta- & $16.8 \pm 0.5^{\mathrm{a}}$ & $22.1 \pm 0.4^{\mathrm{a}}$ \\
\hline
\end{tabular}

Data are presented as means $\pm \mathrm{SEM}, n=3$. Letters at $\mathrm{IC}_{50}$ and $\mathrm{CC}_{50}$ values indicate statistically different observations at $p<0.05$.

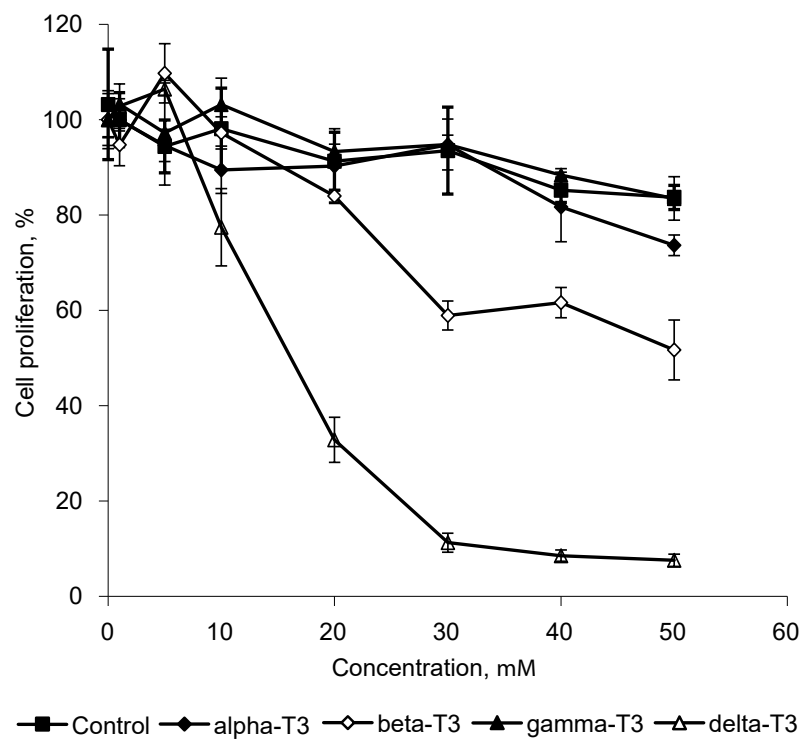

Fig. 4. The cytotoxicity of tocotrienols in the Caco-2 human colon cancer cells. Data are presented as means \pm SEM, $n=3$

tions of all homologs were demonstrated (Fig. 4). The highest $\mathrm{CC}_{50}$ value (Table 2) was calculated for gamma-T3 $(152.4 \mu \mathrm{M})$, followed by alpha-T3 $(72.7 \mu \mathrm{M})$, beta-T3 $(49 \mu \mathrm{M})$ and delta-T3 $(22.1 \mu \mathrm{M})$.

Further studies of PCNA protein expression by Western blot (Fig. 5) did not show any effects of alpha-, beta- and gamma-T3 homologs at four different concentrations $(5,15,30$ and $45 \mu \mathrm{M})$ on the expression of the cell cycle proteins. However, previous colorectal cancer research has ascertained that gamma- and delta-T3 induced apoptosis. Zhang et al. (2013) observed dose dependent inhibition of SW620 and HCT- 8 cell growth that was mediated by an apoptosis-like cell death. Gamma-T3 strongly suppressed the transcriptional activity of b-catenin/Tcf signaling pathway in HT-29 cells (Xu et al., 2012) and impaired cell proliferation by cell-cycle arrest at $\mathrm{G}_{0} / \mathrm{G}$, increased $\mathrm{Bax} /$ Bcl-2 ration, and activation of caspase-3. Kannappan et al. (2010) found that gamma-T3 sensitizes HCT-116 and HT-29 cells to tumor necrosis factor-related apoptosis-inducing ligand (TRIAL) by upregulating death receptors and by downregulating cell survival proteins. Still, future investigation is needed to explain the different mechanism of actions to support the antiproliferative effects of alpha-, beta- and gamma-T3 against colon Caco- 2 cancer cells. 
Szulczewska-Remi, A., Nogala-Kalucka, M. (2020). Studies on the growth inhibiting and non-cytotoxic effects of tocotrienols on selected cancer cell lines. Acta Sci. Pol. Technol. Aliment., 19(2), 139-147. http://dx.doi.org/10.17306/J.AFS.2020.0787

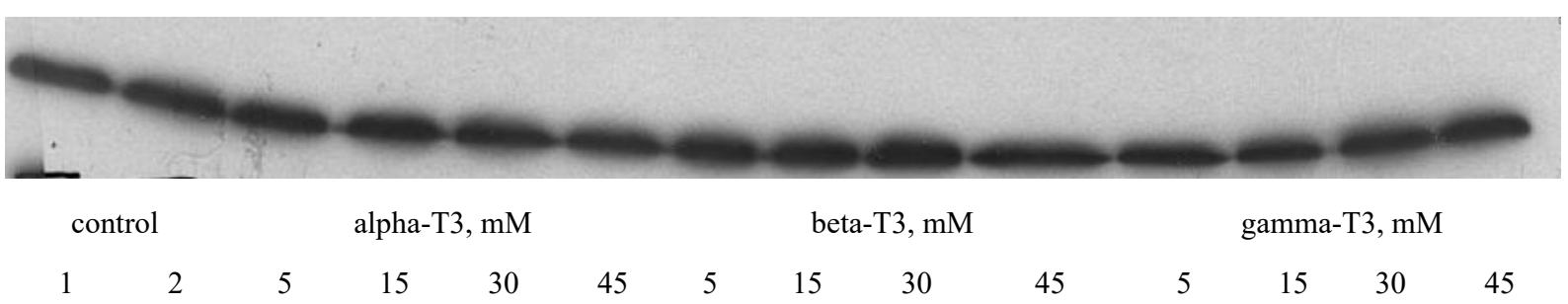

Fig. 5. PCNA protein expression by Western blot of Caco-2 human colon cancer cell line treated with tocotrienols at different concentrations

\section{CONCLUSIONS}

Research conducted over the past several years has confirmed the anticancer effects of tocotrienols against human liver and different colorectal cancer cell lines. In the present study, statistically similar cytotoxic effects of both beta- and delta-T3 with no effects for alpha- and gamma-T3 on $\mathrm{HepG}_{2}$ cells were observed. The exact reasons for the sensitivity of liver cancer cells to tocotrienols are unknown. It is a time and dosedependent inhibition, therefore tocotrienol homologs show very high toxic or no effects. However, promising results of alpha-, beta- and gamma-T3 against Caco-2 human colon cancer cells have been assessed.

Still, future investigation is needed to explain the different mechanism of actions to support the antiproliferative effects of these homologs against colon Caco-2 cancer cells.

\section{REFERENCES}

Abu-Fayyad, A., Nazzal, S. (2017). Extraction of vitamin E isomers from palm oil: Methodology, characterization, and in vitro anti-tumor activity. J. Am. Oil Chem. Soc., 94, 1209-1217.

Aida, J. A. J., Zakiah, J., Gapor, M. T., Wan Nosh, W. Z. (2007). The antiproliferative effect of palm oil gammatocotrienol on isoprenoid pathway of hepatoma cell line. Eur. J. Sci. Res., 18, 576-583.

Bachawal, S. V., Wali, V. B., Sylvester, P. W. (2010). Combined gamma-tocotrienol and erlotinib/gefitinib treatment suppresses Stat and Akt signaling in murine mammary tumor cells. Anticancer Res., 30, 429-437.

Bray, F., Ferlay, J., Soerjomataram, I., Siegel, R. L., Torre, L. A., Jemal, A. (2018). Global cancer statistics 2018: GLOBOCAN estimates of incidence and mortality worldwide for 36 cancers in 185 countries. Cancer J. Clin., 68, 394-424. https://doi.org/10.3322/caac.21492

Campbell, S., Stone, W., Whaley, S., Krishnan, K. (2003). Development of gamma-tocopherol as a colorectal cancer chemopreventive agent. Crit. Rev. Oncol., 47, 249 259.

Chang, P. N., Yap, W. N., Lee, D. T., Ling, M. T., Wong, Y. C., Yap, Y. L. (2009). Evidence of gamma-tocotrienol as an apoptosis-inducing, invasion-suppressing, and chemotherapy drug-sensitizing agent in human melanoma cells. Nutr. Cancer, 61, 357-366.

Comitato, C., Ambra, R., Leoni, G., Virgili, F. (2017). OP-15 - Tocotrienols induce the expression of specific miRNA in breast cancer cells. Free Radic. Biol. Med., 108, S8. https://doi.org/10.1016/j.freeradbiomed.2017.04.054

De Silva, L., Chuah, L. H., Meganathan, P., Fu, J. Y. (2016). Tocotrienol and cancer metastasis. Biofactors, 42, 149 162. https://doi.org/10.1002/biof.1259

Guthrie, N., Gapor, A., Chambers, A. F., Carroll, K. K. (1997). Inhibition of proliferation of estrogen receptornegative MDA-MB-435 and - positive MCF-7 human breast cancer cells by palm oil tocotrienols and tamoxifen, alone and in combination. J. Nutr., 127, 544S$548 \mathrm{~S}$.

Hsieh, T. C. Wu, J. M. (2008). Suppression of cell proliferation and gene expression by combinatorial synergy of EGCG, resveratrol and gamma-tocotrienol in estrogen receptor-positive MCF-7 breast cancer cells. Int. J. Oncol., 33, 851-859.

Hussein, D. Mo, H. (2009). d-Delta-tocotrienol-mediated suppression of the proliferation of human PANC-1, MIA PaCa-2, and BxPC-3 pancreatic carcinoma cells. Pancreas, 38, e124-e136.

Kannappan, R., Gupta, S. C., Kim, J. H., Aggarwal, B. B. (2012). Tocotrienols fight cancer by targeting multiple cell signaling pathways. Genes Nutr., 7, 43-52. https:// doi.org/10.1007/s12263-011-0220-3 
Szulczewska-Remi, A., Nogala-Kalucka, M. (2020). Studies on the growth inhibiting and non-cytotoxic effects of tocotrienols on selected cancer cell lines. Acta Sci. Pol. Technol. Aliment., 19(2), 139-147. http://dx.doi.org/10.17306/J.AFS.2020.0787

Kannappan, R., Ravindran, J., Prasad, S., Sung, B., Yadav, V. R., Reuter, S., ..., Aggarwal, B. B. (2010). Gamma-tocotrienol promotes TRAIL-induced apoptosis through reactive oxygen species/extracellular signalregulated kinase/p53-mediated upregulation of death receptors. Mol. Cancer Ther., 9, 2196-2207. https://doi. org/10.1158/1535-7163.MCT-10-0277

Kashiwagi, K., Harada, K., Yano, Y., Kumadaki, I., Hagiwara, K., Takebayashi, J., ..., Yano, T. (2008). A redoxsilent analogue of tocotrienol inhibits hypoxic adaptation of lung cancer cells. Biochem. Biophys. Res. Commun., $365,875-881$.

Kline, K., Lawson, K. A., Yu, W., Sanders, B. G. (2003). Vitamin $\mathrm{E}$ and breast cancer prevention: current status and future potential. J. Mammary Gland Biol. Neoplas., $8,91-102$.

Komiyama, K., Iizuka, K., Yamaoka, M., Watanabe, H., Tsuchiya, N., Umezawa, I. (1989). Studies on the biological activity of tocotrienols. Chem. Pharm. Bull., 37, 1369-1371.

Kunnumakkara, A. B., Sung, B., Ravindran, J., Diagaradjane, P., Deorukhkar, A., Dey, S., ..., Aggarwal, B. B. (2010) g-tocotrienol inhibits pancreatic tumors and sensitizes them to gemcitabine treatment by modulating the inflammatory microenvironment. Cancer Res., 70, 8695-8705.

Liu, R. H., Jacob, J. R., Tennant, B. C. (1997). Chemiluminescent detection of protein molecular weight markers in Western blot techniques. Biotechniques, 22, 594-595.

McIntyre, B. S., Briski, K. P., Tirmenstein, M. A., Fariss, M. W., Gapor, A., Sylvester, P. W. (2000). Antiproliferative and apoptotic effects of tocopherols and tocotrienols on normal mouse mammary epithelial cells. Lipids, 35. https://doi.org/10.1007/BF0266476

Nesaretnam, K., Dorasamy, S., Darbre, P. D. (2000). Tocotrienols inhibit growth of ZR-75-1 breast cancer cells. Int. J. Food Sci. Nutr., 51, S95-S103.

Oliver, M. H., Harrison, N. K., Bishop, J. E., Cole, P. J., Laurent, J. L. (1989). A rapid and convenient assay for counting cells cultures in microwell plates; application for assessment of growth factors. J. Cell Sci., 92, 518531.

Park, S. K., Sanders, B. G., Kline, K. (2010). Tocotrienols induce apoptosis in breast cancer cell lines via an endoplasmic reticulum stress dependent increase in extrinsic death receptor signaling. Breast Cancer Res. Treat., 124, 361-375.

Pierpaoli, E., Viola, V., Pilolli, F., Piroddi, M., Galli, F., Provinciali, M. (2010). Gamma- and delta-tocotrienols exert a more potent anticancer effect than alpha-tocoph- eryl succinate on breast cancer cell lines irrespective of HER-2/neu expression. Life Sci., 86, 668-675.

Rajendran, P., Li, F., Manu, K. A., Shanmugam, M. K., Loo, S. Y., Kumar, A. P., Sethi, G. (2011). g-Tocotrienol is a novel inhibitor of constitutive and inducible STAT3 signaling pathway in human hepatocellular carcinoma: potential role as an antiproliferative, pro-apoptotic and chemosensitizing. Brit. J. Pharm., 163, 283-298. https:// doi.org/10.1111/j.1476-5381.2010.01187.x

Sailo, B. L., Banik, K., Padmavathi, G., Javadi, M., Bordoloi, D., Kunnumakkara, A. B. (2018). Tocotrienols: The promising analogues of vitamin $\mathrm{E}$ for cancer therapeutics. Pharm. Res., 130, 259-272. https://doi. org/10.1016/j.phrs.2018.02.017

Samant, G. V., Wali, V. B., Sylvester, P. W. (2010). Antiproliferative effects of gamma-tocotrienol on mammary tumor cells are associated with suppression of cell cycle progression, Cell Prolif., 43, 77-83.

Sazli, F. A. R., Jubri, Z., Rahman, M. A., Karsani, S. A., Top, A. G. M., Nghan, W. Z. W. (2015). Gamma-tocotrienol treatment increased peroxiredoxin- 4 expression in HepG2 liver cancer cell line. BMC Comp. Alter. Med., 15, 64. https://doi.org/10.1186/s12906-015-0590-y

Schwenke, D. C. (2002). Does lack of tocopherols and tocotrienols put women at increased risk of breast cancer? J. Nutr. Bioch., 13, 2-20.

Shibata, A., Nakagawa, K., Tsuduk, T., Miyazawa, T. (2015). $\delta$-Tocotrienol treatment is more effective against hypoxic tumor cells than normoxic cells: potential implications for cancer therapy. J. Nutr. Bioch., 26, 832840. https://doi.org/10.1016/j.jnutbio.2015.02.011

Sylvester, P. W., Shah, S. (2005). Intracellular mechanisms mediating tocotrienol-induced apoptosis in neoplastic mammary epithelial cells. Asia Pac. J. Clin. Nutr., 14, 366-373.

Szulczewska-Remi, A., Nogala-Kałucka, M., Nowak, K. W. (2019). Study on the influence of palm oil on blood and liver biochemical parameters, beta-carotene and tocochromanols content as well as antioxidant activity in rats. J. Food Biochem., 43, e12707. https://doi. org/10.1111/jfbc. 12707

Theriault, A., Chao, J., Wang, Q., Gapor, A., Adeli, K. (1999). Tocotrienol: a review of its therapeutic potential. Clin. Bioch., 32, 309-319.

Yang, Z., Xiao, H., Jin, H., Koo, P. T., Tsang, D. J., Yang, C. S. (2010). Synergistic actions of atorvastatin with gamma-tocotrienol and celecoxib against human colon cancer HT29 and HCT116 cells. Int. J. Cancer, 126, $852-863$. 
Szulczewska-Remi, A., Nogala-Kalucka, M. (2020). Studies on the growth inhibiting and non-cytotoxic effects of tocotrienols on selected cancer cell lines. Acta Sci. Pol. Technol. Aliment., 19(2), 139-147. http://dx.doi.org/10.17306/J.AFS.2020.0787

Yano, Y., Satoh, H., Fukumoto, K., Kumadaki, I., Ichikawa, T., Yamada, K., ..., Yano, T. (2005). Induction of cytotoxicity in human lung adenocarcinoma cells by 6-O-carboxypropylalpha-tocotrienol, a redox-silent derivative of alpha-tocotrienol. Int. J. Cancer, 115, 839-846. https:// doi.org/10.1002/ijc.20809

Yap, W. N., Zaiden, N., Luk, S. Y., Lee, D. T., Ling, M. T., Wong, Y. C., Yap, Y. L. (2010). In vivo evidence of gamma-tocotrienol as a chemosensitizer in the treatment of hormone-refractory prostate cancer. Pharmacol., 85, $248-258$.

Wada, S., Satomi, Y., Murkoshi, M., Noguchi, N., Yoshikawa, T., Nishino, H. (2005). Tumor suppressive effects of tocotrienol in vivo and in vitro. Cancer Lett., 229, 181-191. https://doi.org/10.1016/j.canlet.2005.06.036

Wali, V. B., Bachawal, S. V., Sylvester, P. W. (2009). Endoplasmic reticulum stress mediates gamma-tocotrienol- induced apoptosis in mammary tumor cells. Apoptosis, 14, 1366-1377.

Xu, W., Du, M., Zhao, Y., Wang, Q., Sun, W., Chen, B. (2012.) $\gamma$-Tocotrienol inhibits cell viability through suppression of $\beta$-catenin/Tcf signaling in human colon carcinoma HT-29 cells. J. Nutr. Bioch., 23, 800-807. https://doi.org/10.1016/j.jnutbio.2011.04.003

Zaiden, N., Yap, W. N., Ong, S., Xu, C. H., Teo, V. H., Chang, C. P., ..., Yap, Y. L. (2010). Gamma delta tocotrienols reduce hepatic triglyceride synthesis and VLDL secretion. J. Atheroscler. Thromb., 17, 1019-1032.

Zhang, J. S., Li, D. M., Ma, Y., He, N., Gu, Q., Wang, F. S., Jiang, S. Q., ..., Liu, J. R. (2013). g-Tocotrienol induces paraptosis-like cell death in human colon carcinoma SW620 cells. PLOS One, 8, e57779. 